\title{
Tidal current transport of epibenthic swarms of the euphausiid Nyctiphanes simplex in a shallow, sub- tropical bay on Baja California peninsula, México
}

\author{
Jaime Gómez-Gutiérrez ${ }^{1, *}$, Carlos J. Robinson ${ }^{2}$ \\ ${ }^{1}$ Centro Interdisciplinario de Ciencias Marinas, Departamento de Plancton y Ecología Marina, \\ Ave. IPN s/n, Col. Playa Palo de Santa Rita, A.P. 592 La Paz, Baja California Sur C.P. 23096, México \\ ${ }^{2}$ Laboratorio de Ecología de Pesquerías, Instituto de Ciencias del Mar y Limnología, \\ Universidad Nacional Autónoma de México, A.P. 70-305, México D.F. C.P. 04510, México
}

\begin{abstract}
Nyctiphanes simplex is the most prominent neritic euphausiid along the southwest coast of the Baja California peninsula, México. It was thought that this species is usually distributed in areas deeper than $50 \mathrm{~m}$. However, in the mouth of a subtropical bay (Bahía Magdalena, 28 to $50 \mathrm{~m}$ depth) using a $120 \mathrm{kHz}$ split-beam echosounder, a submarine video camera, and a $1 \mathrm{~m}$ plankton net, we discovered that high-density swarms of adult $N$. simplex enter the bay near the seafloor during spring and summer but not in winter, even though flood current speeds were statistically indistinguishable among seasons. Euphausiid transport was modulated by their abundance over the continental shelf, their daily vertical migration, and the semidiurnal tidal currents. From 6 series of $48 \mathrm{~h}$ sampling runs along a $18 \mathrm{~km}$ long transect located through the mouth of the bay, we estimated a set of acoustic parameters to identify euphausiid swarms and distinguish them from aggregations of the abundant local micronektonic galatheid Pleuroncodes planipes. The euphausiid swarms were vertically segregated from the dense aggregations of $P$. planipes. Euphausiids that entered the bay were completely dispersed within strong spring tidal currents $\left(>125 \mathrm{~cm} \mathrm{~s}^{-1}\right)$ and subsequently formed dense aggregations inside the bay, where current speed decreased substantially. Euphausiid distribution inside the bay never extended farther than the continental-shelf water mass delineated by the tidal front. In the bay, adult $N$. simplex remained close to the sea-bottom day and night. We hypothesized that the large euphausiid and red crab biomass transported from the continental shelf into Bahía Magdalena may contribute significantly to the trophodynamics of this eutrophic subtropical bay.
\end{abstract}

KEY WORDS: Nyctiphanes simplex $\cdot$ Acoustics $\cdot$ Euphausiid $\cdot$ Epibenthic aggregation $\cdot$ Swarm formation · Tidal currents · Bahía Magdalena · México

\section{INTRODUCTION}

Nyctiphanes simplex Hansen is the most abundant neritic euphausiid species along the continental shelf of the southern part of the California Current System, the Gulf of California, and the Humboldt Current System (Brinton 1962, Brinton \& Townsend 1980, GómezGutiérrez et al. 1995, Brinton et al. 2000). When using conventional Bongo sampling nets towed from 5 to $10 \mathrm{~m}$ above the seafloor to the sea surface, previous studies had concluded that $N$. simplex usually inhabited areas deeper than $50 \mathrm{~m}$, suggesting that this species avoided shallow environments (Gómez-Gutiérrez 1995, De Silva-Dávila \& Palomares-García 2002). In another study, also using standard Bongo nets to survey throughout the mouth of Bahía Magdalena $\left(24^{\circ} \mathrm{N}\right.$, $112^{\circ} \mathrm{W}$ ), we reported that $N$. simplex larvae (calyptopes and furciliae) but not juvenile and adults occasionally enter the bay, transported by tidal currents (Gómez-Gutiérrez et al. 2001). Contrary to our expec- 
tations, when we used a submarine video camera, a scientific echosounder, and a zooplankton net in this present study, we discovered that dense epibenthic swarms of adult $N$. simplex commonly enter through a relatively shallow (28 to $50 \mathrm{~m}$ depth) section of the main mouth of this subtropical bay.

Gómez-Gutiérrez (1995) and Gómez-Gutiérrez et al. (1996) reported that the abundance, population structure, and secondary production of Nyctiphanes simplex over the continental shelf of Bahía Magdalena demonstrates the formation of dense swarm densities in spring and summer (average 1075 and 2520 ind. $1000 \mathrm{~m}^{-3}$ ) when the cold and rich phytoplankton water mass of the California Current (CC) is intense. The abundance decreased dramatically in the autumn and winter (average 178 ind. $1000 \mathrm{~m}^{-3}$ ) when the water column is warmer, well mixed, and contains low phytoplankton concentration because of the retreat of the $\mathrm{CC}$ toward the north. This seasonal population-density variability could be associated with the amount of euphausiids that potentially enter the bay with the tidal currents.

The planktonic organisms use several strategies to stay in certain regions of shallow bays and estuaries. Among the best known mechanisms are tidally oriented, daily vertical-migration (vertical migration of zooplankton in response to local tides), position maintenance of zooplankton, or high net population growth rates (Kimmerer et al. 1998, Forward \& Tankersley 2001, Gibson 2003). The role of tidal currents in the transport and swarm formation of euphausiids is in general poorly understood; however, this was recently studied for the micronektonic red crab Pleuroncodes planipes Stimpson in Bahía Magdalena (Robinson \& Gómez-Aguirre 2004, Robinson et al. 2004). Cottée \& Simard (2005) studied the daytime, 3-dimensional distribution of Thysanoessa raschi M. Sars and Meganyctiphanes norvegica M. Sars in the St. Lawrence Estuary, Canada, over a semidiurnal tidal cycle during summer and hypothesized that the formation of dense aggregations (>500 $\mathrm{g} \mathrm{m}^{-3}$ wet weight) were formed owing to the combined effect of semidiurnal tidal currents, local topography, and negative phototactism of euphausiids. We explored the oceanographic coupling of tidal currents, temperature, raw fluorescence as a proxy for chl a concentration, and swarming formation to discuss the transport of the subtropical euphausiid Nyctiphanes simplex over the continental shelf and the mouth and inner part of Bahía Magdalena.

Zaytsev et al. (2003) reported that Bahía Magdalena is the largest bay along the west coast of the Baja California peninsula with the steepest continental-shelf slope and the narrowest continental shelf (88 $\mathrm{m}$ drop in depth per $11 \mathrm{~km})$. They hypothesized that an upwelling process near the inlets of these bays, cou- pled with tidal flooding and mixing processes, may transport biological material, grazing organisms, and nutrients into the bay because of the narrow continental shelf. We tested this hypothesis experimentally by studying how seasonal environmental conditions and tidal current-patterns affect the transport of euphausiids inside the bay in conjunction with the relatively well-known population dynamics of this species along the southwestern part of the Baja California peninsula. Our first goal was to estimate acoustic parameters to detect, identify, and distinguish dense Nyctiphanes simplex swarms from another abundant micronektonic crustacean in the region, the red crab Pleuroncodes planipes. Our second goal was to describe the mechanisms of how $N$. simplex is transported into the bay by local currents, and determine how this process affects these euphausiids trapped by the currents. Robinson et al. (2004) and Robinson \& Gómez-Aguirre (2004) showed how $P$. planipes tend to avoid warm water moved by the receding tide (ebb tides) that might pose a risk of becoming stranded on the beach, as does occur in this bay every year (Aurioles-Gamboa et al. 1994). We assumed that $N$. simplex and red crabs interact in such a way that the euphausiids avoid an overlap in distribution with the larger aggregations of the voracious, omnivorous red crab. Our study showed a distinctive pattern of epibenthic $N$. simplex aggregation in shallow waters, not observed in other studies of euphausiid swarming-formation; this supposedly increases chances of mating and finding food and, as an ancillary benefit, may lead to the distraction of predators which become confused by a multitude of prey (Hamner 1984, Strand \& Hamner 1990, Gendron 1992, Ritz 1994, Hamner \& Hamner 2000, Mufti \& Weise 2004, Cottée \& Simard 2005). This study demonstrates the highly-flexible ability of $N$. simplex to modify its vertical migration and swarm-formation behavior in correspondence with local tidal currents, and how this species behaves during its relatively short stay inside the bay; furthermore, we demonstrated that euphausiids do not complete their life cycle in this shallow-bay environment.

\section{MATERIALS AND METHODS}

Sampling of environmental conditions. Acoustic and submarine videotape surveys and euphausiid collections were completed during 4 oceanographic cruises (1 to 18 December 2003, 16 March to 2 April, 29 June to 16 July, and 1 to 18 December 2004) over the continental shelf and in the middle part of Bahía Magdalena, Baja California Sur, México $\left(24^{\circ} 30 \mathrm{~N}, 112^{\circ} 30 \mathrm{~W}\right)$ on board the R/V 'El Puma' (Universidad Nacional Autónoma de México) (Fig. 1A). Bahía Magdalena is a eutrophic sub- 


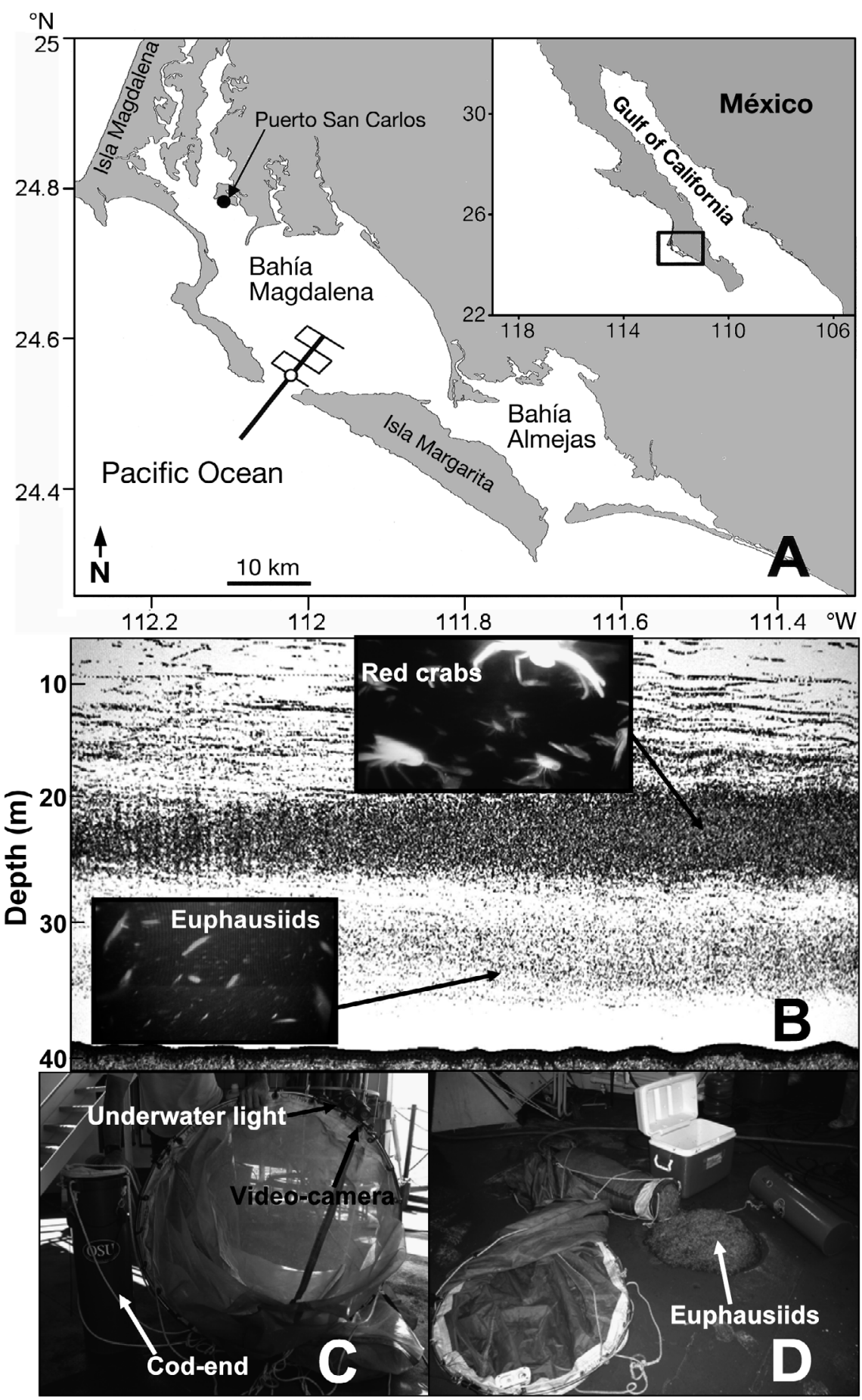

Fig. 1. (A) Bahía Magdalena. Bold line through mouth of bay: $48 \mathrm{~h}$ transect line, traversed during spring and neap tides in December 2003, March, July, and December 2004. Thin parallel lines: 'circuit' where continuous $4 \mathrm{~m}$ depth temperature and fluorescence were monitored over $48 \mathrm{~h}$. O: $24 \mathrm{~h}$ anchorage station sampled every hour during spring and neap tides. (B) Echogram of dense scattering layers in mouth of Bahía Magdalena, detected using a Simrad EY-60 echosounder during slack tide: dense aggregation of the pelagic red crab Pleuroncodes planipes at $25 \mathrm{~m}$; swarm of euphausiid Nyctiphanes simplex at $35 \mathrm{~m}$. (C) Zooplankton net (1 m diameter) used to sample near seafloor, equipped with a submarine video camera, and underwater light. (D) The euphasiid catch was usually abundant and composed of a monospecies N. Simplex. Sporadically, high-density swarms were observed and collected during March and July tropical bay with a tidal wave-energydominated system with a main mouth $4 \mathrm{~km}$ wide (Zaytsev et al. 2003). Our oceanographic cruises included 3 sampling strategies.

Sampling through the mouth of Bahía Magdalena: During each oceanographic cruise we made two $48 \mathrm{~h}$ surveys, each during spring and neap tides, along an $18 \mathrm{~km}$ long transect oriented through the mouth of Bahía Magdalena (Fig. 1A) to record the acoustic scattering layer of planktonic and nektonic organisms. Along the transect, the $4 \mathrm{~m}$ depth temperature $\left({ }^{\circ} \mathrm{C}\right.$; measured with a SeaBird microcat CTD) and fluorescence as a proxy for chl a concentration (measured with a Turner Designs 10-AU005-CE fluorometer) were recorded every $5 \mathrm{~s}$ from seawater pumped from the intake located at the bow of the vessel. Simultaneously, a SonTek 250 $\mathrm{kHz}$ Acoustic Doppler Current Profiler (ADCP) was used to measure current velocity and direction. ADCP transducers were fixed to the vessel's hull at $4 \mathrm{~m}$ depth. Vertical resolution was $2 \mathrm{~m}$ with a pulse interval of $5 \mathrm{~s}$. In order to identify the species for acoustic signals during each transect, we sporadically stopped to quickly submerge a high-resolution Multi SeaCam 1060 video camera (Deep Sea Power \& Light; low-light black and white camera with an $\mathrm{f}=2.8 \mathrm{~mm}$ lens and depth of field from $10 \mathrm{~cm}$ to infinity, equipped with a DVD videorecorder) to depths where the echosounder showed a dense scattering layer.

During the 3 oceanographic cruises conducted during 2004, euphausiid swarms were sampled using a $1 \mathrm{~m}$ diameter net that was $5 \mathrm{~m}$ long, and constructed of black $300 \mu \mathrm{m}$ mesh. The cod end was constructed with gray PVC, and was of $0.215 \mathrm{~m}$ diameter and $0.70 \mathrm{~m}$ height. This net was equipped with an underwater lamp (Ikelite ProVideo-Lite II system, $50 \mathrm{~W}$ ) to attract euphausiids. The submarine video camera mentioned above was attached to the net ring (Fig. 1C).

Euphausiid total length was measured from the posterior part of the 
eye to the tip of the telson, and during each cruise gender and maturity stage of all specimens was determined to obtain seasonal changes in size frequency distribution and population structure. The specimens were separated into 5 categories: juveniles, immature females (females with gonad development Stage I to III), mature females (females with pink gonad Stage IV ready to spawn, ovigerous females, and spent females), immature males (without spermatophore), and mature males (with spermatophore).

At several of the March and July 2004 sampling locations, we captured extremely high densities of euphausiids (Fig. 1D). On such occasions we deployed the video camera alone (without net) attached to a weight $(20 \mathrm{~kg})$ to avoid over sampling of euphausiids with the net. In several locations, the euphausiid swarms were in contact with the seafloor. We collected these epibenthic swarms, which were detected with the help of the echosounder and simultaneously observed with the underwater video camera.

Sampling at an anchorage station in the mouth of Bahía Magdalena: During spring and neap tides of each oceanographic cruise, we made a $24 \mathrm{~h}$ acoustic survey, zooplankton collections, and submarine video camera observations at an anchorage station located at $24^{\circ} 33.34^{\prime} \mathrm{N}, 112^{\circ} 01.07^{\prime} \mathrm{W}$ (Fig. 1A). These observations helped us to identify the acoustic targets and to study euphausiid swarming behavior: swarm compactness and swimming orientation of individual organisms recorded with the video camera. We selected the anchorage station from spring tides in March 2004, because this was our best example of how euphausiids and red crabs were simultaneously and heavily aggregated but in different depth layers (almost monospecific swarms), and later began to disperse demonstrating a relatively large variety of swarming behavior. In March, July and December 2004 we corroborated the presence of both common and abundant species at the anchorage station with ground-truth video camera and net samples.

Continuous sampling within Bahía Magdalena (circuits): After these 2 sampling strategies were completed, we monitored the $4 \mathrm{~m}$ depth fluorescence, temperature, current speed and direction continuously (every $5 \mathrm{~s}$ ) and simultaneously recorded the acoustic scattering layer with 3 pulses $\mathrm{s}^{-1}$ over $48 \mathrm{~h}$ during spring and neap tides, along 4 transects within Bahía Magdalena that were $\sim 6.5 \mathrm{~km}$ long and separated from each other by $1.8 \mathrm{~km}$ (Fig. 1A). The average duration of each circuit was about $3.5 \mathrm{~h}$. The raw fluorescence data (V) measured with the fluorometer (excitation 340 to $500 \mathrm{~nm}$, emission $>665 \mathrm{~nm}$ ) were used as a proxy for chlorophyll concentrations.

Acoustic identification of euphausiid swarms. During December 2003 and March and July 2004, we used a Simrad EY-60 split-beam echosounder. The operational frequency was $120 \mathrm{kHz}$ with a nominal beam transducer width of $7^{\circ}$. The transducer was fixed on the vessel's hull at $4 \mathrm{~m}$ depth. Ping rate was set to 3 pings per second and pulse duration $0.1 \mathrm{~ms}$. Calibration was conducted before each oceanographic cruise in Mazatlán, México $\left(23^{\circ} 16^{\prime} \mathrm{N}, 106^{\circ} 26^{\prime} \mathrm{W}\right)$, home port to R/V 'El Puma', according to Simrad ER-60 operation manual guidelines (Simrad 2003). The reference target was a copper sphere supplied by Simrad $(120 \mathrm{kHz}$, $23 \mathrm{~mm}$ diameter, target strength $[\mathrm{TS}]=-40.4 \mathrm{~dB}$ ). For acoustic data analysis we used the SONAR-4 software version 5.9. During December 2004, no acoustic data were recorded. Because euphausiid samples were not collected during December 2003, we used samples from December 2004 to determine the winter $\mathrm{NYC}_{\mathrm{C}-}$ tiphanes simplex population structure.

The volume backscattering coefficient $\left(s_{V}\right)$ is a measure of the efficiency with which the echosound is scattered back to the source, and is defined by MacLennan et al. (2002) as:

$$
s_{V}=\frac{\sum \sigma_{b s}}{V}
$$

where $\sigma_{b s}$ is the backscattering cross-section $\left(\mathrm{m}^{2}\right)$ of the discrete targets in the volume $(V)$. We used the logarithmic version of this coefficient (mean volume backscattering strength, $S_{v}$ ) expressed in decibels, defined by MacLennan et al. (2002) as:

$$
S_{v \mathrm{~dB}}=10 \log _{10}\left(S_{V}\right)
$$

The area backscattering coefficient $\left(s_{a}\right)$ is the backscattering below an area (MacLennan et al. 2002), and it is described as:

$$
S_{a}=\int_{z_{1}}^{z_{2}} S_{V} \mathrm{~d} z
$$

where $z_{1}$ and $z_{2}$ are the depth of the echo integration. The software SONAR-4 calculates $s_{a}$ with a scaling area factor, which in the present study was hectares with corresponding integration layer of $10 \mathrm{~m}$. Thus, with this software $s_{a}$ is calculated as:

$$
S_{a}=4 \pi \times(100 \mathrm{~m})^{2} \times 10^{s_{v}} \text { mean } / 10 \times(10 \mathrm{~m})
$$

In Bahía Magdalena there are dense aggregations of both Pleuroncodes planipes and Nyctiphanes simplex. Mean carapace length of the pelagic phase of $P$. planipes is about $2.5 \mathrm{~cm}$ (benthic phase is $>3.2 \mathrm{~cm}$ ) (GómezGutiérrez \& Sánchez-Ortíz 1997), which is significantly different from adult euphausiids with mean $1.3 \mathrm{~cm}$ total length (Gómez-Gutiérrez 1995, this study). However, dense aggregations of euphausiids may produce a backscattering strength similar to or stronger than a single red crab. Therefore, acoustic identification and separation of both species can be complicated. The analysis 
of $S_{V}$ is an appropriate method to discriminate these targets because it is standardized to a volume of $1 \mathrm{~m}^{3}$. We then assumed that the back scattering strength per volume is stronger for red crab than for euphausiids.

During the anchorage-sampling protocol, we made detailed analyses of echograms at depths where wellidentified monospecific swarms of Pleuroncodes planipes or Nyctiphanes simplex were detected. To do this, we first used our experience in observing echograms in the area (which amounts to more than $10 \mathrm{yr}$ ), then confirmed identification of those echoes using an in situ submarine video camera or zooplankton catch obtained with the $1 \mathrm{~m}$-diameter zooplankton net with the submarine video camera attached to the ring of the live net. Next, echograms were stored in the computer and analyzed using SONAR-4. This program is able to calculate $S_{V}$ values from stored echograms for every ping in vertical layers of $50 \mathrm{~cm}$ thickness.

The aim of this analysis was to determine the ranges of $S_{V}$ values for both species under the following patchiness conditions: Pleuroncodes planipes in dense aggregations and well-dispersed, and Nyctiphanes simplex in dense swarms and also well-dispersed. This acoustic characterization was a frame of reference to estimate and compare euphausiid and red crab abundance among oceanographic cruises under similar aggregation conditions. Therefore, it is possible that less-dense aggregations of euphausiids or red crabs than our observed may not be detected with our selected acoustic parameters, thereby perhaps underestimating total abundance. The main acoustic reference for dense monospecific swarms of $N$. simplex and $P$. planipes was observed during a $24 \mathrm{~h}$ anchorage station at $35 \mathrm{~m}$ and at $25 \mathrm{~m}$ layer depth $\left(24^{\circ} 32.98^{\prime} \mathrm{N}\right.$, $112^{\circ} 01.14^{\prime} \mathrm{W} ; 30$ March 2004, between 21:00 and 22:00 h). A selected section of this echogram ( 30 min of records) is presented in Fig. 1B and shows 2 wellseparated scattering layers, one composed of dense red crab aggregations and the second of dense euphausiid swarms. The dispersed euphausiids were detected when swarms began to separate. On 31 March at 14:55 $\mathrm{h}$ at the same anchorage station, only dispersed red crabs were observed with the video camera system and were recorded acoustically.
Using the $s_{V}$ analysis, Nyctiphanes simplex swarms were acoustically identified and separated from Pleuroncodes planipes aggregations (Table 1). The most significant difference in $S_{V}$ values was between dispersed euphausiid swarms and dense aggregations of red crabs (Mann-Whitney $U$-test, p < 0.05). Aggregated $N$. simplex and dispersed $P$. planipes provided similar yet statistically-distinguishable values of $S_{V}$ (Mann-Whitney $U$-test, p $<0.05$, Table 1).

To estimate the Nyctiphanes simplex distribution and abundance we filtered the $S_{V}$ values from the echograms recorded during $48 \mathrm{~h}$ surveys in the spring and neap tides of each oceanographic cruise. We used only the values recorded for aggregated $N$. simplex (ranging from first quartile $q_{1}=-66.2 \mathrm{~dB}$ to third quartile $q_{3}=-61.2 \mathrm{~dB}$ ). With those values, we were able to calculate the back scattering area $\left(s_{a}\right)$ as described above. The analyzed acoustic area was about $3500 \times$ $10 \mathrm{~m}$ and began $2 \mathrm{~m}$ above the sea floor (Fig. 8B).

TS in decibels is the logarithmic version of $\sigma_{b s}$ and, after MacLennan et al. (2002), is expressed as:

$$
\mathrm{TS}=10 \log _{10}\left(\sigma_{b s}\right)
$$

As far as we know, the TS of subtropical euphausiids including Nyctiphanes simplex has not been directly measured. We did not measure field TS values of $N$. simplex with SONAR-4 because most of the targets observed in the echograms were from multiple individuals, even in the most dispersed situation. We therefore used the relationship of known average total length of the euphausiids detected by sound during our study, but scaled to measured target strength for a slightly larger euphausiid species as:

$$
\mathrm{TS}=20 \log (\text { mean total length })-75.7 \mathrm{~dB}
$$

This relation was calculated for the euphausiid Euphausia pacifica Hansen (measured total length ranged from 11 to $19 \mathrm{~mm}$; however, this species may reach up to $25 \mathrm{~mm}$ total length), which has a similar body morphology but is slightly larger than $\mathrm{Nyc}$ tiphanes simplex and was detected with a $102 \mathrm{kHz}$ frequency (MacLennan \& Simmons 1992). Accordingly, the estimated TS of a single $N$. simplex of total length $13 \mathrm{~mm}$ (Fig 9A-D) should be approximately -73.4 dB.

Table 1. Nyctiphanes simplex and Pleuroncodes planipes. Mean volume backscattering strength $\left(S_{v i} \mathrm{~dB}\right)$ recorded over $48 \mathrm{~h}$ on 30 March 2004 at anchorage station near mouth of Bahía Magdalena. n: number of pings analyzed; $q_{1}$ : first quartile (25\% of total observations); $q_{3}$ : third quartile (75\% of total observations)

\begin{tabular}{|lrccccc|}
\hline Species and form of aggregation & $\mathrm{n}$ & Median & Min. & Max. & $q_{1}$ & $q_{3}$ \\
\hline N. simplex dispersed & 10854 & -66.7 & -69.9 & -61.0 & -67.9 & -65.0 \\
N. simplex aggregated & 7854 & -63.9 & -69.9 & -55.1 & -66.2 & -61.2 \\
P. planipes dispersed & 4556 & -58.7 & -64.1 & -43.4 & -60.8 & -55.8 \\
P. planipes aggregated & 4556 & -58.1 & -65.1 & -46.2 & -60.9 & -55.5 \\
\hline
\end{tabular}




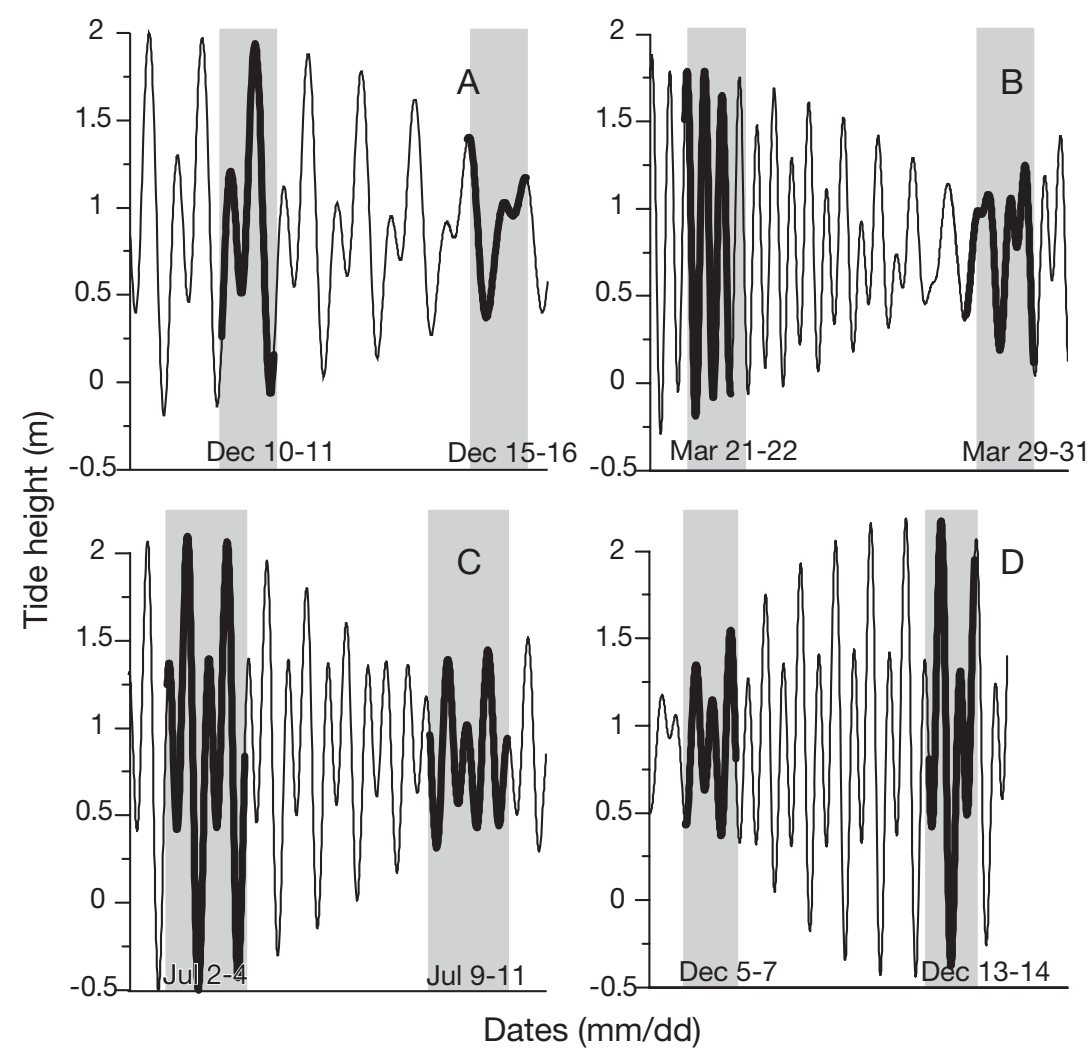

Fig. 2. Seasonal tidal height in Bahía Magdalena. (A) December 2003, (B) March 2004, (C) July 2004, (D) December 2004. Grey areas: periods during spring and neap tides when biological and physical variables were recorded

$$
\rho=s_{a} / \sigma_{b s}
$$

We plotted euphausiid abundance (standardized to ind. $\mathrm{m}^{-3}$ ) estimated acoustically during spring and neap tides for each oceanographic survey and compared that with the modeled tidal height predicted by software JTides version 4.8 (www.arachnoid. com/JTides/). Observational and modeled tidal information indicates that the tidal regime in Bahía Magdalena is mixed and semidiurnal.

\section{RESULTS}

\section{Seasonal changes in tidal height and current speed}

In Bahía Magdalena there is a semidiurnal tidal pattern with maximum range of $2.5 \mathrm{~m}$, but the magnitude of the first and second daily peaks and lows change significantly both seasonally and during spring and neap tides (Fig. 2A-D). The semidiurnal pattern (timing) associated with range and tidal height played a significant role in the transport of plankton and micronekton through the mouth of the bay

Next we calculated a backscattering cross-section $\sigma_{b s}=$ $4.5 \times 10^{-8} \mathrm{~m}^{2}$ using the above mentioned TS with the following equation:

$$
\sigma_{b s}=10^{(\mathrm{TS} / 10)}
$$

As an alternative, we used the average TS value of -91.5 dB reported for the Antarctic euphausiid species Euphausia superba Dana (corresponding for an individual E. superba of $13 \mathrm{~mm}$ total length) to estimate Nyctiphanes simplex abundance (Demer \& Conti 2003, 2004). As total length of adult E. superba ranges between 45 and $65 \mathrm{~mm}$, a total length of $13 \mathrm{~mm}$ likely represents the length of a larvae furcilia Stage VI (8 to $15.5 \mathrm{~mm}$ ) or small juveniles (Brinton et al. 2000), which are probably more slender and occur in different densities to adult $N$. simplex. However, when using a TS of $-91.5 \mathrm{~dB}$, the calculated backscattering cross-section $\sigma_{b s}=7.08 \times 10^{-10} \mathrm{~m}^{2}$ would represent an abundance of $N$. simplex about 38 times greater than that estimated with the TS of $-73.4 \mathrm{~dB}$ from Euphausia pacifica. Finally, the density of targets expressed as the number per unit volume $\left(\rho=\right.$ ind. $\mathrm{m}^{-3}$ ) between depths $z_{1}$ and $z_{2}$ (in this present study, $z_{2}-z_{1}=10 \mathrm{~m}$ ) was obtained as in MacLennan et al. (2002): not only on a diurnal time-scale (inflow and outflow), but also when it was compared between spring and neap tides. However, current speeds measured with the ADCP recorded during spring tide (at flood) were statistically indistinguishable among seasons (KruskalWallis, p > 0.05) (Fig. 3). Highest current speeds (up to $125 \mathrm{~cm} \mathrm{~s}^{-1}$ ) were recorded near the mouth of the bay, perhaps as result of a funneling effect caused by the abrupt change of topography from $\sim 90 \mathrm{~m}$ depth to $\sim 40 \mathrm{~m}$ at the mouth of the bay (Zaytsev et al. 2003). That current speed did not change seasonally indicates that, hydrodynamically, tidal currents could potentially transport a similar amount of planktonic and nektonic organisms through the mouth of the bay independent of season. Thus, currents are not a limiting factor of organism transport through the mouth of the bay.

However, as mentioned later, our biological information indicates that local eutrophic conditions during March and July promote large zooplankton and micronekton biomass production, favoring their transport into the bay, whereas during the oligotrophic conditions that prevail during December (both years) a significantly smaller biomass is moved through the mouth of the bay. 


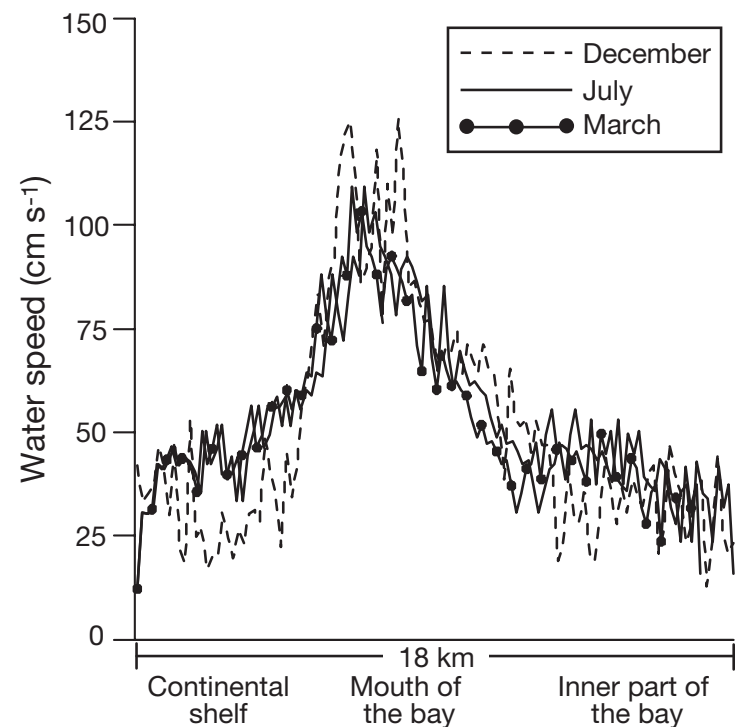

Fig. 3. Seasonal current speed measured at $15 \mathrm{~m}$ along the oceanographic transect (18 km long) through mouth of Bahía

Magdalena during maximum flood phase in spring tides

\section{Seasonal changes in $4 \mathrm{~m}$ depth temperature during spring and neap tides (circuits)}

The continuous $4 \mathrm{~m}$ depth temperature $\left(T_{4}\right)$, recorded throughout the mouth and within Bahía Magdalena along 4 transects monitored over $48 \mathrm{~h}$ at each tidal phase (spring and neap tides), showed a clear seasonal signal, with the first quartile $\left(q_{1}, 25 \%\right.$ of total observations) and third quartile $\left(q_{3}, 75 \%\right.$ of total observations) of $T_{4}$ ranging between 15.8 and $18.2^{\circ} \mathrm{C}$ in March 2004, 15.6 and $20.4^{\circ} \mathrm{C}$ in July 2004, and between 21.3 and $22.4^{\circ} \mathrm{C}$ in December 2003 and 2004 (Fig. 4A). Variability in $T_{4}$ was relatively large in March and July during spring and neap tides, and thermal condition variability was smaller and more homogeneous during December of both years (Fig. 4A). During March and July 2004, median $T_{4}$ were significantly lower during spring tides than during neap tides (Mann-Whitney $U$-test, $\mathrm{p}<0.05$ ). The opposite was observed during December 2003 and 2004, with a significantly lower $T_{4}$ during neap tide than during spring tide (Mann-Whitney $U$-test, p < 0.05). Overall, $T_{4}$ variability was less pronounced during both Decembers than during the March and July oceanographic cruises in both tidal states (Fig. 4A).

\section{Seasonal changes in $4 \mathrm{~m}$ depth fluorescence during spring and neap tides (circuits)}

The $4 \mathrm{~m}$ depth fluorescence $\left(\mathrm{F}_{4}\right)$ as a proxy of the chl a ( $\mathrm{chl} \mathrm{a}_{4}$ ) showed typical moderate levels during March 2004, with $q_{1}$ and $q_{3}$ values between 5 and 9 volts in spring tides and increasing during neap tides to 7 and 14 volts of fluorescence. This difference probably reflected a reduction in phytoplankton export from the bay to the continental shelf during neap tides (MannWhitney $U$-test, p < 0.05). During summer (July 2004), $\mathrm{F}_{4}$ peaked during spring tides with $q_{1}$ and $q_{3}$ (14 to 22.5 volts of fluorescence) associated with a lower $T_{4}$. During neap tides, significantly lower $\mathrm{F}_{4}$ values (11.5 to 14.5 volts of fluorescence) were recorded than during spring tides (Mann-Whitney $U$-test, p < 0.05). However, those $\mathrm{F}_{4}$ values were within the range observed during neap tides in March. During winter low $\mathrm{F}_{4}$ values prevailed, usually $<9$ volts of fluorescence in December 2003, and $<6$ volts of fluorescence in December 2004 (Fig. 4B). During both months of December, significantly higher $\mathrm{F}_{4}$ values were recorded during neap tides than during spring tides (Mann-Whitney $U$-test, $\mathrm{p}<0.05)$. It is interesting that during March and July high variability $\left(q_{1}\right.$ and $q_{3}$ ) was recorded between and within spring and neap tide periods, whereas during December in both years, $\mathrm{F}_{4}$ values were homogeneous during a $48 \mathrm{~h}$ period throughout the area surveyed (Fig. 4B).

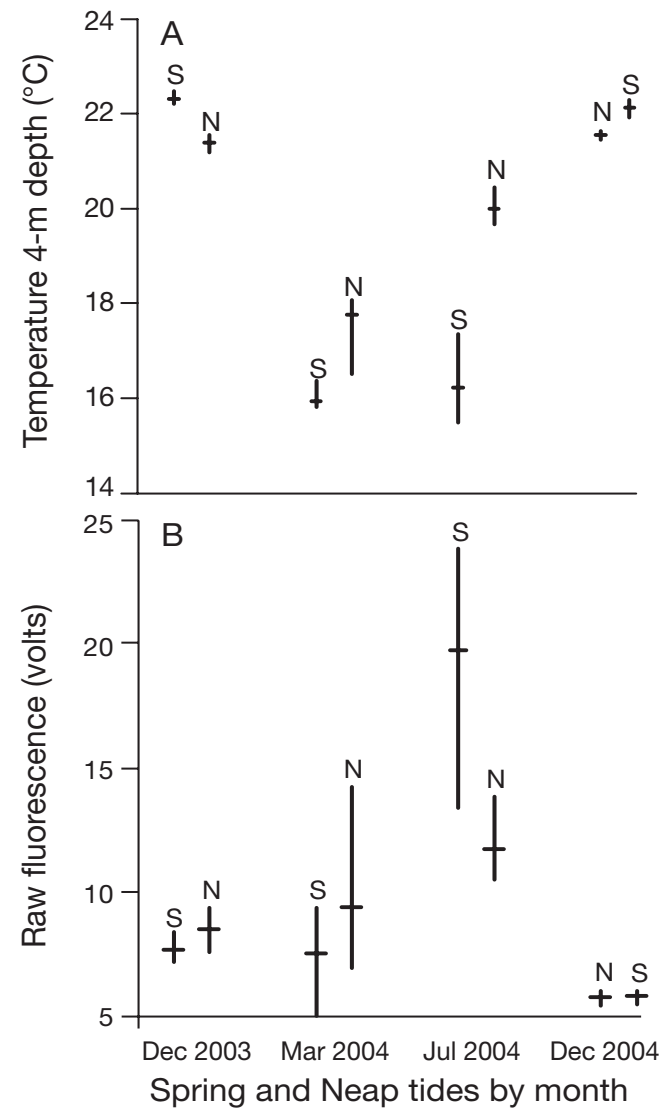

Fig. 4. Seasonal median, $q_{1}$ and $q_{3}$ of continuous (A) $T_{4}$ and (B) raw fluorescence ${ }_{4}$ as a proxy for chl $a_{4}$ along circuits (Fig. 1A) in December 2003, March, July, and December 2004. S: spring tides; N: neap tides 


\section{Patterns of distribution of $4 \mathbf{m}$ depth temperature along transect}

Tidal fronts were easily detected visually and instrumentally (using the spring tide continuous $T_{4}$ along the transect through the mouth of Bahía Magdalena during flood and ebb conditions) in March and July 2004, but they were not observed in December 2003.

$T_{4}$ showed that in winter (December 2003), temperature was homogeneously warm $\left(22\right.$ to $\left.23^{\circ} \mathrm{C}\right)$ along the entire hydrographic line with an almost imperceptible thermal front located over the continental shelf of Bahía Magdalena (Fig. 5A). During March 2004, the thermal front exhibited a dramatic $T_{4}$ gradient $\left(\Delta \sim 3^{\circ} \mathrm{C}\right)$ near the mouth of the bay during ebb tides and within the bay during flood tides. The tidal front moved approximately $6 \mathrm{~km}$ inside the bay between tidal phases. $T_{4}$ was lower over the continental shelf than within the bay because of wind-induced upwelling that tended to cool the deeper part of Bahía Magdalena during maximum inflow (Fig. 5B). In July 2004, the thermal front was even stronger than during March $\left(\Delta \sim 4^{\circ} \mathrm{C}\right)$, and the tidal front also moved about $6 \mathrm{~km}$ inside the bay between flood and ebb tide phases. However, $T_{4}$ was higher over the continental shelf than within the bay during ebb tides, and $T_{4}$ was lower over the continental shelf than within the bay during maximum flood tides. This was probably caused by the combined effect of higher solar radiance (causing an intense and shallower thermocline) and stronger upwelling events over the continental shelf moving recently-upwelled water into the bay (Fig. 5C).

\section{Advection of plankton and micronekton by tidal currents}

Although it is sometimes difficult to identify a functional group of organisms directly from echograms, the dense scattering layer (SL) analysis provides an insight into how those aggregations migrate vertically and are transported horizontally by local currents. As an example of plankton and micronekton transport through the mouth of the Bahía Magdalena associated with tidal height, we show the tidal-height cycle, indicating with a bold line and sequential letters (A-L) the periods when acoustic information was recorded during a $48 \mathrm{~h}$ sequence of echograms (spring tides, 17 to 19 March 2004) (Fig. 6). On each echogram is shown the initial and final times used to delimit the acoustic data set (Fig. 7 A-L). The mouth of the bay is identified by the abrupt rise of the seafloor to a depth of about $35 \mathrm{~m}$. All echograms showed a dense SL, composed of macroplanktonic and micronektonic organisms, in the deeper region over the continental shelf ( 90 to $60 \mathrm{~m}$

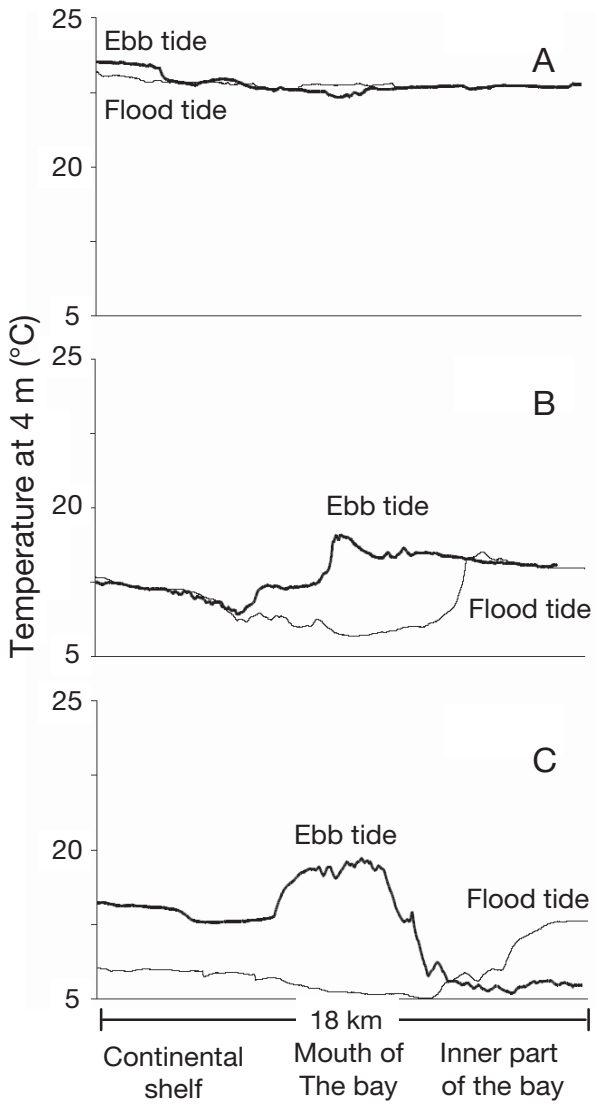

Fig. 5. Seasonal $T_{4}$ recorded continuously through mouth of Bahía Magdalena (18 km transect) in (A) December 2003, (B) March 2004, and (C) July 2004. Bold line measured during outflowing (ebb) spring tides; thin line recorded during inflowing (flood) spring tides. Location of tidal front according to tidal phase detected by abrupt changes in $T_{4}$

depth). During the nighttime sections of the echograms, the SL migrated upward to near surface layers $(<25 \mathrm{~m}$ depth), whereas during the day the SL was deeper (>50 $\mathrm{m}$ depth). If the plankton-nekton upward nighttime-vertical migration coincided with the inflowing tide, part of this dense SL was transported into the inner-most part of the bay delimited by the tidal front (Fig. 7E,H). However, this also occasionally occurred during the day when a relatively dense SL was recorded near the mouth (Fig. $7 \mathrm{~K}$ ). Most commonly, if the inflowing tide occurred during the day, when most of the organisms were usually in deeper waters, a relatively small amount of pelagic organisms were transported into the bay only within the region near the mouth $(<3 \mathrm{~km}$ inside the bay) (Fig. 7B). This distribution also occurred at night when the tidal height started to increase immediately after an ebb tide (Fig. 7). During strong, diurnal ebb tides, the SL was scarce in the mouth and inner region of the bay (Fig. $7 \mathrm{I}, \mathrm{L}$ ) or only moderately abundant (Fig. 7A,F,G). During nighttime ebb tides, dense scattering layers were recorded in the 


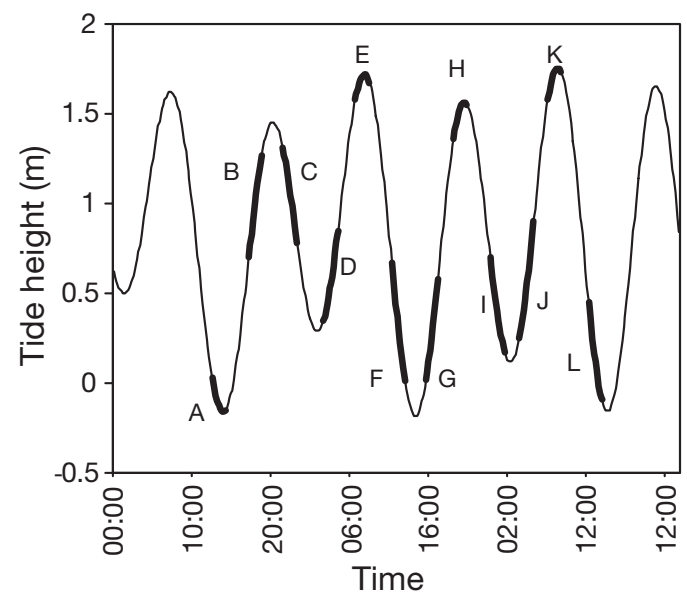

Fig. 6. Tidal height in Bahía Magdalena, 17 to 19 March 2004 (spring tides). Bold line: periods when sound-scattering layer was recorded using a split-beam echosounder (see echograms in Fig. 7)

mouth of the bay when the pelagic organisms were being transported out of the bay (Fig. 7C).

As predicted by the tidal height pattern, the massive SL intrusion inside the bay occurred twice per day, but this process was quite asymmetrical because of the combined effect of the daily vertical migration of the pelagic organisms (dependent on time and light intensity) and the tidal current speed and direction pattern (current velocity). The identification of the main components of those dense SLs at specific places along the oceanographic transect were deduced from video analysis and samples collected with a zooplankton net in regions where the echosounder indicated a dense SL. All this information showed that aggregations of Pleuroncodes planipes, Nyctiphanes simplex, and the copepod Calanus pacificus Brodsky comprised a large portion of the total acoustic signals recorded. Small pelagic schools (Pacific sardine Sardinops sagax Jenyns, and Pacific mackerel Scomber japonicus Houttuyn) were also observed and were distinguishable from the plankton, because fish schools are smaller and acoustic signals were well above those obtained from plankton and red crabs.

\section{Seasonal changes in euphausiid abundance and advection of swarms during spring and neap tides estimated by echosounding}

Euphausiid swarms were commonly recorded acoustically and with the video camera during March and July 2004 as dense near-bottom aggregations (between 1 and $10 \mathrm{~m}$ above the seafloor near the mouth of the bay) both day and night, or as dense midwater aggregations (40 to $100 \mathrm{~m}$ ) over the continental shelf. During both December cruises, euphausiid swarms were observed less frequently and with smaller density than in spring and summer cruises. A typical echogram in March (Fig. 1B), recorded at the anchorage station in the mouth of Bahía Magdalena, shows dense aggregations of Pleuroncodes planipes at midwater depths and dense monospecific swarms of Nyctiphanes simplex near the seafloor. During July, the $P$. planipes aggregations were again observed with comparable abundances; however, the euphausiid aggregations were relatively smaller and less frequently observed than in March. Over the continental shelf of Bahía Magdalena and at offshore stations (>100 m depth), $N$. simplex migrates vertically on a daily basis, showing near-surface dense aggregations at night and dispersed aggregations during the day (Robinson \& Gómez-Gutiérrez 1998a). However, in the mouth of Bahía Magdalena, the euphausiids were invariably observed as epibenthic aggregations without any evidence of typical daily vertical migration. Results of the density of targets (ind. $\mathrm{m}^{-3}$ ) when using the average TS for Euphausia pacifica $(-73.4 \mathrm{~dB})$ were plotted as a function of time and compared with tidal height (Fig. 8 A-F). If using a TS of $-91.5 \mathrm{~dB}$, predicted by the stochastic distorted-wave Born approximation model (SDWBA) for Euphausia superba individuals of average total length $13 \mathrm{~mm}$ (Demmer \& Conti 2003, 2004), the abundances of $N$. simplex estimated acoustically would be 38 times greater than those shown in Fig. 8.

In general, euphausiid abundance inside the bay was directly associated with tidal height, except during spring tides in the July 2004 cruise when no apparent association was observed. During December 2003 (spring tides), euphausiid abundance was usually $<100$ ind. $\mathrm{m}^{-3}$ (Fig. 8A). No acoustic data were recorded during neap tides on this cruise. Dense euphausiid swarms (up to 160 ind. $\mathrm{m}^{-3}$ ) entered the bay in March 2004 during spring tides (Fig. 8C), but abundance was substantially reduced $\left(<40\right.$ ind. $\left.\mathrm{m}^{-3}\right)$ during neap tides (Fig. 8D). In spring tides of the July 2004 cruise, acoustic abundance of euphausiids did not show any association with tidal currents (Fig. 8E). It is possible that euphausiids were swimming in a more dispersed manner than in March, or were out of our range of the volume analyzed for $S_{V}$. The abundance of euphausiids within the bay in July increased again during neap tides, and was closely associated with tidal current transport (Fig. 8F).

\section{Population structure of Nyctiphanes simplex swarms inferred from zooplankton net collections}

Seasonal euphausiid abundance was corroborated by field data from euphausiids collected with a zooplankton net. In March 2004, euphausiids were col- 
lected in 17 out $23(74 \%)$ zooplankton net tows made during the $18 \mathrm{~d}$ cruise ( $\mathrm{n}=1338$ euphausiids). In July, euphausiid swarms were less frequently collected in the mouth of Bahía Magdalena, but they were more common and abundant over the continental shelf. We collected euphausiids in 10 out 19 (53\%) stations sampled during the $18 \mathrm{~d}$ ( $\mathrm{n}=501$ euphausiids). In December 2004, euphausiids were extremely difficult to col-
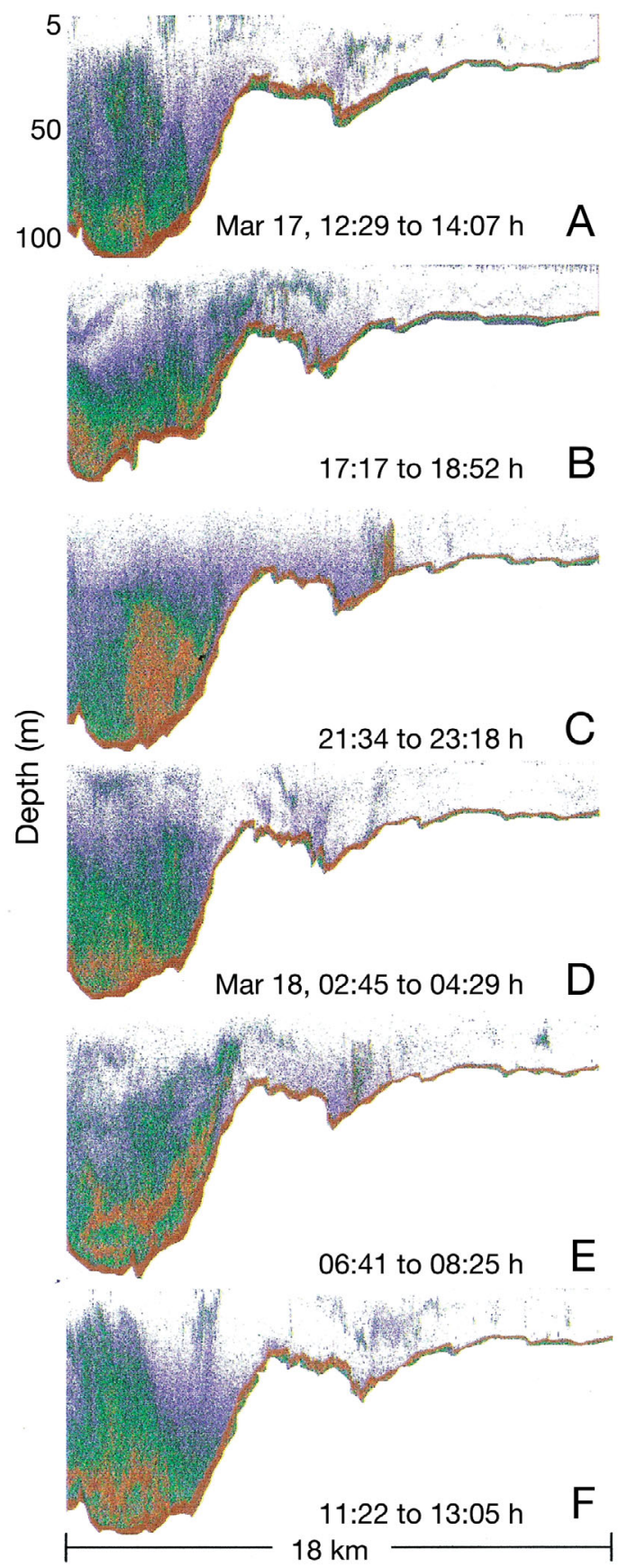
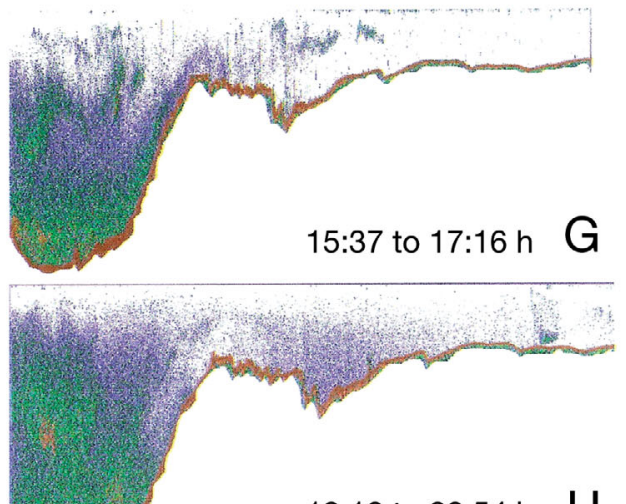

19:10 to $20: 54$ h $\mathrm{H}$

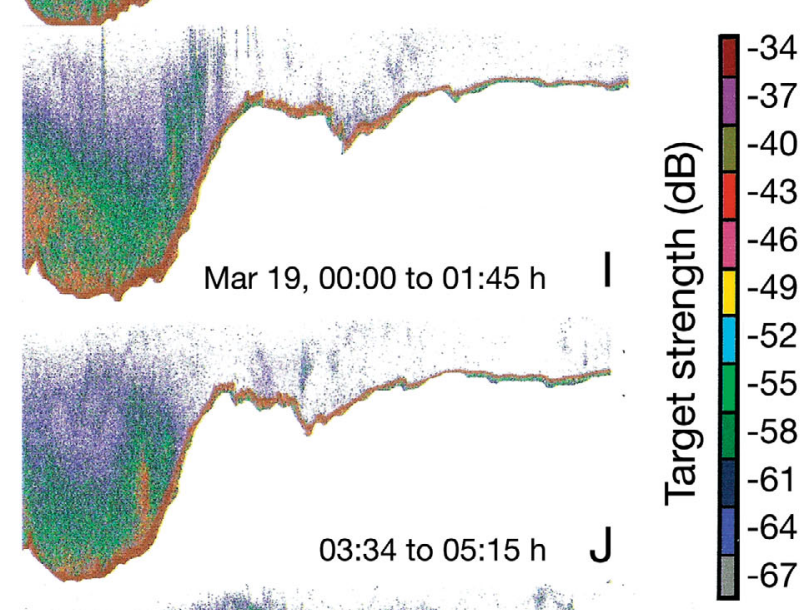

07:09 to $08: 51$ h K

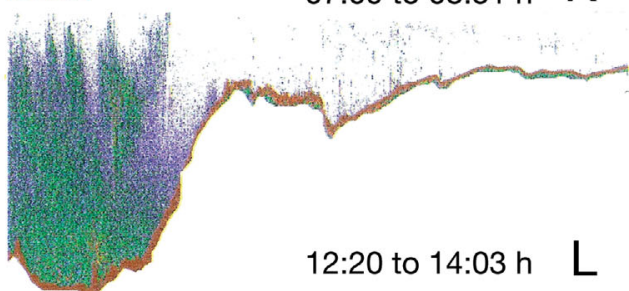

Fig. 7. A 48 h sequence (17 to 19 March 2004) of echograms recorded through the mouth of Bahía Magdalena during spring tides. Echograms show scattering layer (SL) composed of a myriad of zooplanktonic and nektonic organisms that entered the bay with strong flood-tide currents (up to $125 \mathrm{~cm} \mathrm{~s}^{-1}$ ). SL was mainly composed of aggregations of pelagic euphausiid Nyctiphanes simplex, calanoid copepod Calanus pacificus, pelagic red crab Pleuroncodes planipes, and schools of Pacific sardine Sardinops sagax and mackerel Scomber japonicus. Initial and final local time shown on each echogram and tidal height shown in Fig. 6 demonstrate that (1) during ebb tide (outflow) the SL is retracted to the mouth and (2) during inflow (high tidal height) the SL enters the inner part of the bay 

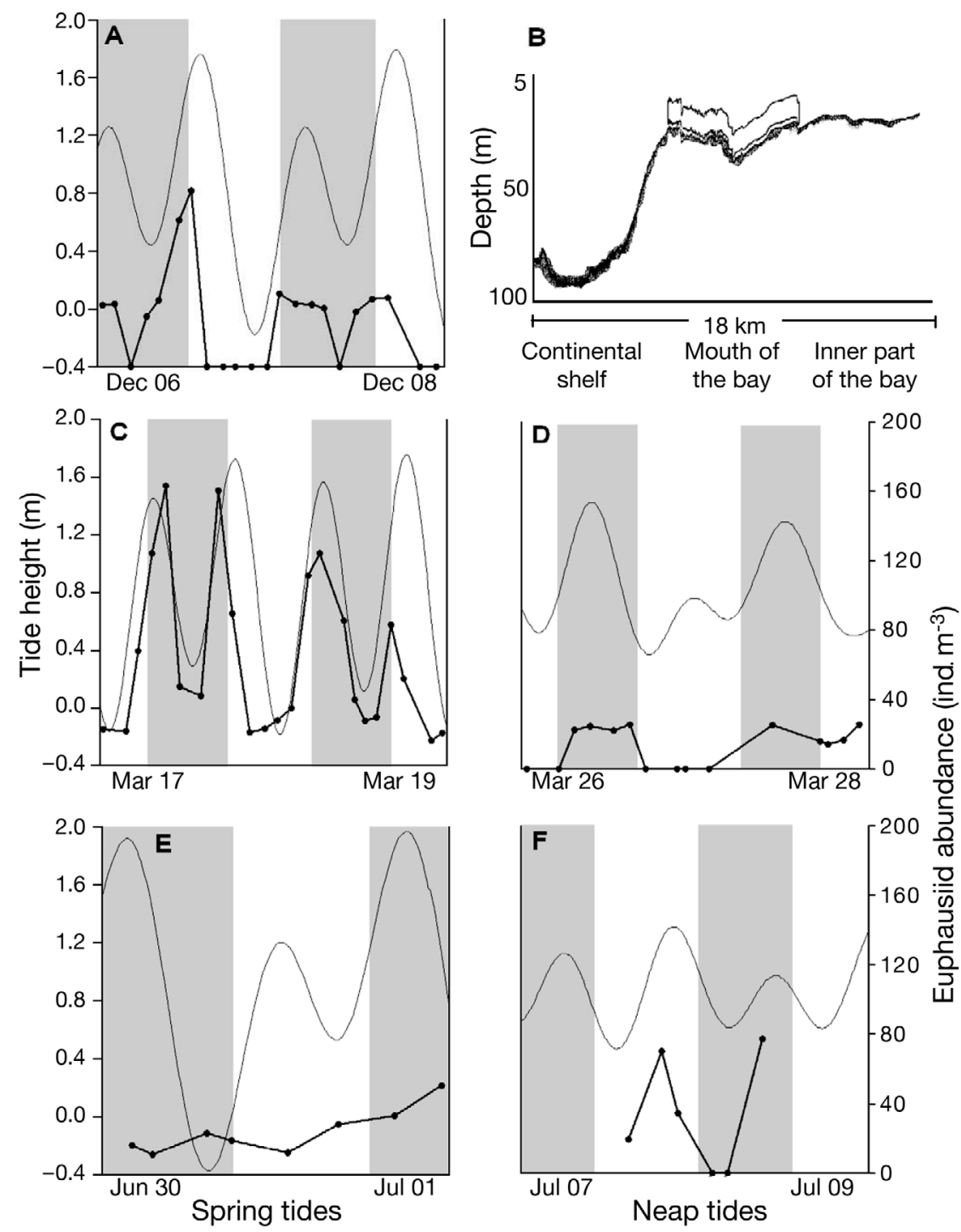

Fig. 8. Nyctiphanes simplex. Epibenthic swarms in mouth of Bahía Magdalena, detected using acoustic parameters obtained from observations of dense monospecies swarms at a $24 \mathrm{~h}$ anchorage station. Dense swarms entered during flood tides and receded from the bay during ebb tides in (A) December 2003 (spring tides), (C, D) March 2004 (spring and neap tides), (E, F) July 2004 (spring and neap tides). (B) Topography of mouth of Bahía Magdalena where acoustic sampling transect was made, showing the section and depth where acoustical analysis was performed. Grey areas indicate night sampling periods

lect because they did not form dense aggregations and because they were mostly located outside the bay over the continental shelf. We collected euphausiids in low densities at 16 stations ( $\mathrm{n}=268$ euphausiids) from a total of $33(48 \%)$ zooplankton samples collected during December 2004.

During March and July, the euphausiid population structure was comprised of a large proportion of animals in the reproductive stage (females with pink gonads in meiosis stage filling the cephalothorax until the first abdominal segment, and males with spermatophores)
(Fig. 9A,B,D,E). When comparing stations located over the continental shelf and the mouth and inner part of Bahía Magdalena, in March we collected larger animals within the bay than over the continental shelf. In July, the size structure was similar in both regions (Fig. 9B,E). In December 2004, the euphausiids collected were substantially smaller than those in the previous 2 oceanographic cruises (Fig. 9C,D). Although reproductive euphausiids were present in similar proportions in both regions, smaller organisms were observed in the mouth of the bay than over the continental shelf (Fig. 9C,F). Juveniles were opportunistically collected and Fig. 9 does not reliably reflect their field abundance. The total length at first maturity for Nyctiphanes simplex males and females is about 8 mm (Fig. 9), and the larger euphausiids collected measured $18.6 \mathrm{~mm}$ total length.

\section{Video camera observations of swarming behavior of Nyctiphanes simplex}

The number of video camera deployments and total hours of video recorded was significantly greater in March 2004 than in the other oceanographic cruises, even excluding the March $200449 \mathrm{~h}$ of continuous video recording at the anchorage station (40 $\mathrm{m}$ depth). Excluding this experiment, the number of casts and hours of video per cruise in 2004 were: March cruise, 42 casts, 27 h; July cruise, 12 casts, 8 h; December 2004 cruise, 1 casts, $18 \mathrm{~h}$. In the mouth and inner part of the bay, we observed swarms of Nyctiphanes simplex adults swimming exclusively close to the seafloor. The swarming behavior of N. simplex was associated with the tidal-current speed. During flood tides, with current speeds up to $125 \mathrm{~cm} \mathrm{~s}^{-1}$, the euphausiids were dispersed and moved semi-passively with the current. They were detected with the video camera and their characteristic fast and linear swimming-pathways clearly distinguished them from smaller and more passive zooplankton. After the tidal height reached maximum inflow (slack tide) the current speed decreased substantially. In the innermost part of 

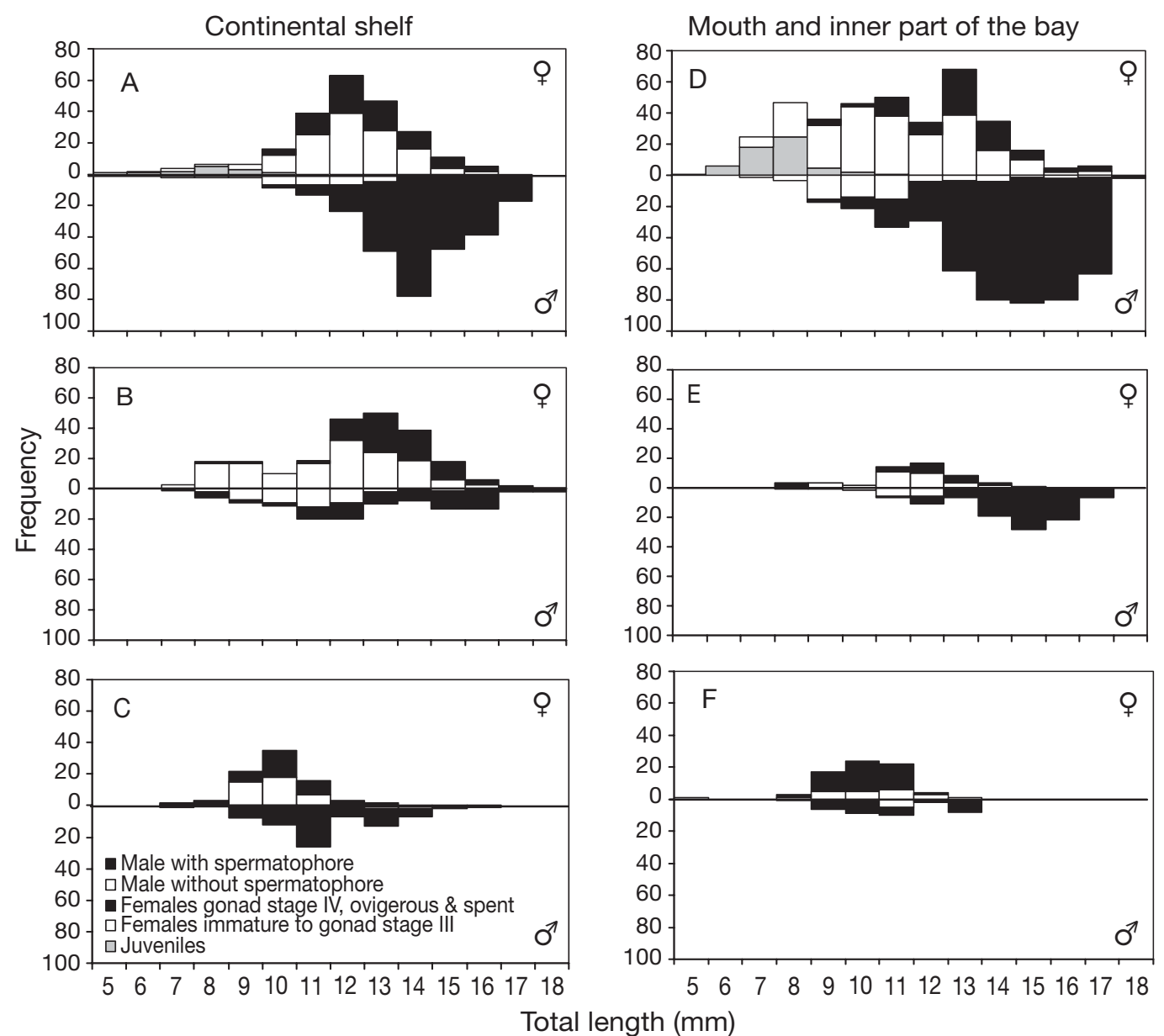

Fig. 9. Nyctiphanes simplex. Size-frequency distribution and population structure for specimens collected over continental shelf in (A) March ( $\mathrm{n}=511)$, (B) July $(\mathrm{n}=345)$, and $(\mathrm{C})$ December $2004(\mathrm{n}=160)$ and specimens collected in mouth and inner part of Bahía Magdalena in (D) March ( $\mathrm{n}=847),(\mathrm{E})$, July $(\mathrm{n}=156)$, and (F) December $2004(\mathrm{n}=108)$

the bay, the $N$. simplex swarms were more aggregated and swam continuously in an eddy-like motion near the seafloor, with no evidence of polarized swimming among individuals within the swarm, which means that each euphausiid usually had a different swimming pathway-much like that of an individual in a bee swarm rather than in a uniformly-oriented swimming school of fish (Ritz 1994). Unlike Euphausia superba, where the schools are usually thin in at least 1 dimension (Hamner 1984), N. simplex swarms exhibited relatively small spherical or cylindrical swarms where individuals located in the center may move to the border of the swarms occasionally. The coherence of the swarms lasted for hours, particularly during nighttime. Interaction among adults within the swarm was probably related to reproduction, as evidenced by population structure in this region (Fig. 9A-F). However, we did not directly observe the mating process owing to the video camera resolution and apparent chaos within the swarm. Euphausiid swarms were not observed during December 2003 and 2004.

\section{DISCUSSION}

\section{Seasonal variability in environmental conditions}

Traditionally, it has been thought that seasonal and interannual changes in sea surface temperature and chl a patterns in Bahía Magdalena were the greatest source of variability (Palomares-García \& GómezGutiérrez 1996, Lluch-Belda et al. 2000, PalomaresGarcía et al. 2003), rather than circadian or daily sampling at an anchorage station (Aceves-Medina et al. 1992, Palomares-García \& Vera-Alejandre 1995, Gómez-Gutiérrez et al. 1999a, Robinson \& GómezAguirre 2004) or along a hydrographic line through the mouth or inner part of Bahía Magdalena (GómezGutiérrez et al. 2001, Zaytsev et al. 2003, Robinson et al. 2004). On a seasonal time-scale, variability in temperature and fluorescence as a proxy for chl a patterns observed in the present study was similar to that reported in previous studies, with lower temperatures and chl a during spring, a moderate increase in tem- 
perature and a sharp peak in chl a during the springsummer transition, and warmer and relatively oligotrophic conditions during autumn and winter (Gómez-Gutiérrez et al. 2001, Palomares-García et al. 2003). However, we recorded $T_{4}$ and $F_{4}$ as a proxy for chl $a_{4}$ with high-frequency sensors over shorter timescales, associated with diurnal and tidal time-scale variability, and found significantly higher hour- to dayscale variability than previously reported. We were surprised that during spring tides of the July cruise, $T_{4}$ was significantly colder and $F_{4}$ much more highly elevated within the bay than during neap tides. This is an unprecedented observation for Bahía Magdalena, because $T_{4}$ between these 2 tidal periods was highly variable, exceeding well-known seasonal variability that has a time-scale of months. Observed variability in $T_{4}$ between spring and neap tides could not be explained solely by upwelling intensity, because spectral variability derived from the coastal upwelling index is usually 0.5 cycles $d^{-1}$ (Zaytsev et al. 2003), which is significantly longer than spectral variability recorded during our tidal-scale study (>1.5 cycles $\left.\mathrm{d}^{-1}\right)$.

This has significant ecological implications for resident pelagic and plankton organisms in the bay, as environmental conditions change abruptly within days. However, such rapid environmental differences associated with spring and neap tides were apparently restricted to summer. During March, the combination of intensification of the cold $\mathrm{CC}$, moderate solar radiation and high wind speeds, which induces upwelling over the continental shelf, did not cause significant changes in $T_{4}$ and $F_{4}$ during spring and neap tides within the bay. However, during July, when the CC is less intense and solar radiation significantly increases, there were marked changes in temperature between spring and neap tides within the bay. This was caused by a funneling effect and the intrusion of cold upwelled waters $\left(<17^{\circ} \mathrm{C}\right)$ into the warmer and shallower waters in the bay, which was more intense in spring than in neap tides. During December, the CC usually retracts toward the north allowing the tropical north equatorial current to invade the continental shelf and part of Bahía Magdalena. This current significantly increases the temperature and forms a thick ( $30 \mathrm{~m})$, warm, wellmixed layer in the mouth of the bay (Gómez-Gutiérrez et al. 2001). Thus, waters from the continental shelf and the inner part of the bay were warm and statistically indistinguishable. The combined effect of local bottom topography (from 90 to $30 \mathrm{~m}$ depth along $\sim 11 \mathrm{~km}$ ), wind-induced intermittent upwelling events, and periodic tidal currents that enhance turbulent mixing processes near the mouth of Bahía Magdalena create conditions that enhance high rates of plankton production in spring and summer and high rates of plankton transport during flood and ebb tides.

\section{Selective tidal stream of Nyctiphanes simplex in the mouth of Bahía Magdalena}

Using a submarine video camera, we demonstrated that Nyctiphanes simplex exhibited a different aggregation behavior than previously observed: it formed dense epibenthic swarms in the shallower mouth of Bahía Magdalena modulated by tidal currents, which did not migrate vertically. This species is traditionally considered as a neritic, shorter daily vertical-migrator (Brinton 1962, 1967). However, recent studies have shown that $N$. simplex is highly flexible with regard to its daily vertical-migration (DVM) pattern, forming day-time surface swarms (Gendron 1992) or under-taking typical DVM that is concentrated over shelf-break areas (Robinson \& Gómez-Gutiérrez 1998a, GómezGutiérrez et al. 1999b). This indicates the existence of highly intraspecific and geographically-dependent population DVM behavior that is tuned to local mesoscale variability in environmental conditions. Occurrences of highly-abundant epibenthic euphausiid aggregations over continental shelves or in shallow waters have been attributed to (1) reduced current speeds that promotes retention of swarms for several days (Ressler et al. 2005), (2) funneling effects that increase the concentration of zooplankton over seamounts and banks (Genin 2004), or (3) the combining effect of tidal currents, local topography, and negative phototactism of euphausiids (Cottée \& Simard 2005).

We have evidence that part of the Nyctiphanes simplex population inhabiting the continental shelf of Bahía Magdalena seems to be trapped by tidal currents after being transported into the bay. The amount of euphausiids introduced into the bay is regulated by synchronization of the nighttime ascent of euphausiids over the continental shelf and the strong flood tidal currents. Obviously, these 2 processes do not occur symmetrically as strong flood currents might occur during daytime when euphausiids are deeper and beyond the influence of near-surface tidal currents. The highest current speed recorded with the ADCP was always in the mouth of Bahía Magdalena and was caused by the funneling effect. An interesting observation made during our study was that the speed of the strongest flood tide currents during spring tides was statistically indistinguishable among seasons. Thus, in theory a relatively similar amount of euphausiids should be introduced into the bay on a monthly basis if euphausiid biomass were constant over the continental shelf. Thus, variability would be explained just by physical advection from tidal currents.

However, advection is just part of the story, the other part being represented by seasonal variability in swarming formation. In March, high-density $\mathrm{NyC}_{\mathrm{C}}$ tiphanes simplex swarms were frequently observed 
with video cameras and recorded acoustically; the occurrence of such swarms moderately decreased in July, and became infrequent during December even when monitored with the ROV and a video camera (SeaBotix, with a color and black and white camera) (December 2004). Because N. simplex abundance, population structure, and secondary productivity pattern over the continental shelf of Bahía Magdalena is highly seasonal and influenced by CC environmental and current pattern variability (Gómez-Gutiérrez 1995, Gómez-Gutiérrez et al. 1996), the entrance of euphausiids into the bay is a highly dynamic process. Tidal currents introduce euphausiid swarms only when euphausiids are highly abundant over the continental shelf and when the daily vertical distribution coincides with inflowing tidal currents. During spring and summer, upwelling events pump elevated nutrient concentrations into the bay and promote elevated phytoplankton concentrations near the mouth (Zaytsev et al. 2003), even though this is a region with a low zooplankton resident-time during intense flood and ebb tides. Upwelling and downwelling events also play a role in cross-shelf transport of plankton. For example, relatively slow-swimming bivalve veligers do not behave as passive particles (they are not always swept offshore by upwelling or onshore by downwelling) but, contrary to prediction, when larvae are distributed below the thermocline they are swept onshore during upwelling and offshore during downwelling. When larvae are found above the thermocline, cross-shelf transport is as predicted (Shanks \& Brink 2005). Observational studies describe a series of situations where zooplanktonic organisms migrating vertically in the water column on a background of tidal currents would experience considerable horizontal transport (Hill 1991, 1995, Forward \& Tankersley 2001). However, these mechanisms may not work if zooplanktonic animals do not retain a migration behavior synchronized with the lunar semidiurnal tide in shelf waters, where horizontal transport by the $\mathrm{M}_{2}$ tide component would not be expected (Marta-Almeida et al. 2006).

The by-product of day-night epibenthic aggregations of euphausiids suggests a behavioral DVM change, where euphausiids invade shallower waters and stay near the seafloor to avoid potential visual predators like seabirds, small pelagic fish, or red crabs near the surface. However, this apparent epibenthic distribution may also indicate that euphausiids transported to near the surface are actually preyed on significantly, which reduces their near-surface concentrations. Pleuroncodes planipes forms high-density aggregations during spring and early summer as part of its offshore-to-inshore reproductive migration (Aurioles-Gamboa et al. 1994, Gómez-Gutiérrez \& SánchezOrtíz 1997), making them voracious grazers and predators of phytoplankton and zooplankton (Aurioles-Gamboa \& Pérez-Flores 1997). However, during autumn and winter when there is a warmer temperature regime and scarce food, red crabs migrate offshore or northward and almost disappear from Bahía Magdalena. This partially explains why red crabs were observed over the continental shelf in low abundance but not in the mouth or within the bay during either of the December oceanographic cruises. Red crabs selectively remain at midwater depths with frequent upward swimming movements with the abdomen flipping where highest flood current speeds (30 to $50 \mathrm{~cm}$ $\mathrm{s}^{-1}$ ) occur in the mouth of Bahía Magdalena, but they tend to occur in greater concentrations in areas with lower current speeds near the seafloor during the receding tide (Robinson \& Gómez-Aguirre 2004, Robinson et al. 2004). This contrasts with the rapid $(<1 \mathrm{~h})$ red crab DVM recorded over the continental shelf along the west coast of the Baja California peninsula (Robinson \& Gómez-Gutiérrez 1998b). The highest current speeds during ebb tides occur between the surface and $15 \mathrm{~m}$, and during flood tides between 10 and $20 \mathrm{~m}$ (Robinson \& Gómez-Aguirre 2004). Euphausiid swarms were commonly recorded near the seafloor, and near-seafloor current speeds were considerably slower during both tidal phases $\left(<25 \mathrm{~cm} \mathrm{~s}^{-1}\right)$.

Using continuous $T_{4}$ records through the mouth of the bay, we reported that water from the continental shelf moves about $6 \mathrm{~km}$ into the bay with the tidal front. Euphausiids never crossed the tidal front invading the bay water mass. This distance is within the range previously reported of $5 \mathrm{~km}$ (Robinson et al. 2004) and 8 to $10 \mathrm{~km}$ (Zaytsev et al. 2003). Kimmerer et al. (1998) demonstrated that in temperate estuaries, mysids and amphipods showed tidally-oriented vertical migration sufficient to override the net seaward flow to produce a net landward flux of organisms. Migration of copepods, however, was insufficient to reverse or even greatly diminish the net seaward flux of organisms, implying species-specific alternative mechanisms of position maintenance. Even $\mathrm{Nyc}-$ tiphanes simplex adults have relatively strong swimming abilities; video records showed that they were easily transported as semi-passive zooplankters through the mouth of the bay, particularly during spring tides. Euphausiids tended to form dense coherent swarms only during slack tides, when the euphausiids engaged in a more social behavior and formed dense swarms, perhaps related to reproduction as suggested by the high proportion of mature adults in zooplankton samples (Fig. 9).

The existence of epibenthic Nyctiphanes simplex swarms was first indicated by indirect evidence derived from the diet and stomach content of the demersal whitefish Caulolatilus princeps Jenyns in Bahía 
de La Paz on the southwest coast of the Gulf of California (Elorduy-Garay \& Caraveo-Patiño 1994). This teleost fish species is a passive predator that feeds mainly during daylight upon organisms associated with the seafloor. Therefore, the $N$. simplex DVM could be a regular food source for epibenthic zooplanktophagous predators. This episodic and epibenthic trophic interaction may occur in Bahía Magdalena when flood tides transport a large biomass of euphausiids into the bay, which then become available to autochthonous demersal predators.

During March 2004, the estimated euphausiid biomass that entered through the mouth of Bahía Magdalena during the 2 flood phases in spring tides (Fig. 8C) was about $74 \mathrm{t} \mathrm{d}^{-1}$. This $N$. simplex biomass was calculated (assuming an individual TS of $-73.4 \mathrm{~dB}$ for $13 \mathrm{~mm}$ total length) as the product of (1) current net inflow from the seafloor to $10 \mathrm{~m}$ above, where euphausiid swarms were usually observed, assuming a net inflow of $43000 \mathrm{~m}^{3} \mathrm{~s}^{-1}$ during $12 \mathrm{~h}$ (this is one quarter of total net flow $172000 \mathrm{~m}^{3} \mathrm{~s}^{-1}$ measured with our ADCP [19 to 23 March 2003 during spring tides]) along a cross-section of the mouth of Bahía Magdalena (6.5 $\mathrm{km}$ wide $\times 40 \mathrm{~m}$ average depth) (SánchezMontante 2003); (2) the modal value of euphausiid abundance recorded acoustically during the 2 flood tide periods (20 ind. $\mathrm{m}^{-3}$, Fig. 8C), and (3) euphausiid biomass, assuming an average individual euphausiid wet weight of $2 \mathrm{mg}$ ind. $^{-1}$ (average $13 \mathrm{~mm}$ total length) (GómezGutiérrez \& Robinson 1997). This is a conservative euphausiid biomass estimation flux, because standardized abundance estimated acoustically and episodically recorded up to 170 ind. $\mathrm{m}^{-3}$; in addition, previous studies suggest that acoustic methods produce estimates of euphausiid swarm density much below that of visual estimations (Hamner \& Hamner 2000).

Our video camera records occasionally showed euphausiid aggregations with densities probably of the order of $>1000$ ind $\mathrm{m}^{-3}$, estimated before they were attracted by the video camera light. Using TS for a euphausiid with an average total length of $13 \mathrm{~mm}$, predicted with the stochastic distorted-wave Born approximation model (SDWBA) (Demmer \& Conti 2003), the estimated biomass of euphausiids that enter the bay would be about $2812 \mathrm{t} \mathrm{d}^{-1}$ - equivalent to average euphausiid densities of 760 ind. $\mathrm{m}^{-3}$. Although similarly high euphausiid densities were occasionally observed in individual swarms by the video cameras, it is unlikely that this high biomass actually represent the average abundance of euphausiids that enter Bahía Magdalena, because euphausiids tend to form patchy swarms. This clearly exemplifies the relevance of directly measuring TS of $N$. simplex, because biomass estimation strongly depends on the TS selected. Kaartvedt et al. (2005) estimated that a single
Meganyctiphanes norvegica M. Sars swarm in the Norwegian Sea of about $380000 \mathrm{~m}^{3}$ and numerical density of 200 ind. $\mathrm{m}^{-3}$ had a total biomass of $11 \mathrm{t}$. Thus, it is evident that a significant $N$. simplex biomass is frequently introduced into the bay with the flood tide currents. Our range of estimated euphausiid biomass was from 0.12 to $1.02 \mathrm{~g} \mathrm{~m}^{-3}$ (20 to 170 ind. $\mathrm{m}^{-3}$ ), which is relatively smaller than previous acoustic estimations of euphausiid biomass over the continental shelf of the Bering Sea (0.7 to $21 \mathrm{~g} \mathrm{~m}^{-2}$; Coyle \& Pinchuk 2002), or acoustic estimates of biomass that occasionally reached values that exceeded $500 \mathrm{~g} \mathrm{~m}^{-3}$ in the St. Lawrence Estuary that were equivalent to 1500 to 45000 ind. $\mathrm{m}^{-3}$ (Cottée \& Simard 2005).

Using hydroacoustic data, Everson \& Bone (1986) and Demer \& Conti $(2003,2004)$ demonstrated that Euphausia superba swarms remained unchanged in structure during daylight and throughout the night, even though density of swarms appears to change dayto-night because of a change in the orientation of krill in swarms. We observed that Nyctiphanes simplex swarms in the mouth of Bahía Magdalena remained relatively unchanged for periods longer than $6 \mathrm{~h}$ during our $24 \mathrm{~h}$ anchorage observations. Acoustic echograms may indicate apparently solid masses of euphausiids that (at least theoretically) may impose serious problems to individuals in the center, if euphausiids near the periphery harvest all the food. However, Hamner (1984) reported that most E. superba swarms were thin in at least 1 dimension and that some of their spread-out formations were in fact hollow domes. Epibenthic N. simplex swarms observed in Bahía Magdalena were moderately sized (3 to $20 \mathrm{~m}$ length) but never showed a well-synchronized swimming process among members of the aggregation, suggesting that individuals temporarily located in the center of a swarm may easily move to the periphery. This probably reflects different swarming behavior and dynamics between subtropical and Antarctic euphausiid species.

In summary, our study was conducted on a diurnal time-scale with equipment to record high-frequency variability, which was focused over a hydrodynamic mouth of a subtropical bay where tidal currents and inherent plankton DVM behavior modulates most vertical-horizontal transport of plankton aggregations. The euphausiid Nyctiphanes simplex is frequently trapped by tidal currents and temporarily enters the highly productive waters of Bahía Magdalena; however, it is thereby probably also exposed to bayresident predators. The distribution of $N$. simplex near the seafloor during day and night in this area indicates a modification in the DVM known for the species, or may simply reflect of significantly higher predation rates in shallower waters. Possibly, similar epibenthic 
swarms of other neritic euphausiid species episodically enter relatively shallow bays, which could be observed if studied with the adequate methodology and thus expand our knowledge of typical marine environments for euphausiids.

Acknowledgements. This research was partially supported by Centro Interdisciplinario de Ciencias Marinas from Instituto Politécnico Nacional (Vital rates and secondary production of zooplankton in the southern part of the California Current, CGPI 20040013), CONACyT (Survey of secondary production, population dynamics, and parasitism of key zooplankton species by means of in situ incubations and hydro-acoustic methods in the Gulf of California, FOSEMARNAT-2004-01144), Ecology of crustacean galatheids (pelagic phase) and ichthyoplankton with emphasis on demersal species in the gulf of California, SAGARPA S007-2005-1-11717, and the Universidad Nacional Autónoma de México (Dynamics of the pelagic ecosystem of Bahía Magdalena). We thank O. Zaytsev (CICIMAR-IPN) for his valuable and critical comments on the original manuscript and N. Sánchez-Reyes and K. ArroyoRamírez for their technical assistance. We thank 3 anonymous reviewers for their comments that significantly improved this manuscript. We thank the R/V 'El Puma' crew and students and scientists from the Fisheries Ecology Laboratory (ICMyLUNAM) for their cooperation in collection of the acoustic and zooplankton samples. Both authors were supported by SNI fellowships, and J.G.-G. by COFAA-IPN and EDI-IPN grants. Thanks to Dr. E. Glazier for editing the English text.

\section{LITERATURE CITED}

Aceves-Medina G, Saldierna-Martínez R, Hernández-Rivas ME (1992) Variación diurna de la abundancia de larvas de peces en la boca de Bahía Magdalena, Baja California Sur, México. Rev Invest Cient Univ Auton Baja Calif Sur (Ser Cienc Mar) 3:61-70

Aurioles-Gamboa D, Castro-González MI, Pérez-Flores R (1994) Annual mass stranding of pelagic red crabs Pleuroncodes planipes (Crustacea: Anomura: Galatheidae), in Bahía Magdalena, Baja California Sur, México. Fish Bull 92:464-470

Aurioles-Gamboa D, Pérez-Flores R (1997) Seasonal and bathymetric changes in feeding habits of the benthic red crab Pleuroncodes planipes (Decapoda, Anomura, Galatheidae) off the Pacific coast of Baja California Sur, México. Crustaceana 70:272-287

Brinton E (1962) The distribution of Pacific euphausiids. Bull Scripps Inst Oceanogr Univ Calif 8:51-270

Brinton E (1967) Vertical migration and avoidance capability of euphausiids in the California Current. Limnol Oceanogr 12:451-483

Brinton E, Townsend AW (1980) Euphausiids in the Gulf of California-the 1957 cruises. Calif Coop Ocean Fish Invest Rep 21:211-236

Brinton E, Ohman MD, Townsend AW, Knight MD, Bridgeman AL (2000) Euphausiids of the world ocean. Expert Center for Taxonomic Identification, Amsterdam

Cottée C, Simard Y (2005) Formation of dense krill patches under tidal forcing at whale feeding hot spots in the St. Lawrence estuary. Mar Ecol Prog Ser 288:199-210

Coyle KO, Pinchuk AI (2002) The abundance and distribution of euphausiids and zero-age pollock on the inner shelf of the southeast Bering Sea near the inner front in 1997-1999. Deep-Sea Res II 49:009-6030
Demer DA, Conti SG (2003) Reconciling theoretical versus empirical target strengths of krill: effects of phase variability on the distorted-wave Born approximation. ICES J Mar Sci 60:429-434

Demer DA, Conti SG (2004) Erratum. Reconciling theoretical versus empirical target strengths of krill: effects of phase variability on the distorted-wave Born approximation. ICES J Mar Sci 61:157-158

De Silva-Dávila R, Palomares-García R (2002) Distributional patterns of the euphausiid community structure in Bahía de La Paz, B.C.S., México. In: Hendricks ME (ed) Contributions to the study of East Pacific crustaceans. Universidad Nacional Autónoma de México, p 109-125

Elorduy-Garay JF, Caraveo-Patiño J (1994) Feeding habits of the ocean whitefish, Caulolatilus princeps Jenyns 1842 (Pisces:Branchiostegidae), in La Paz Bay, B.C.S., México. Cienc Mar 20:199-218

Everson I, Bone DJ (1986) Effectiveness of the RMT 8 system for sampling krill (Euphausia superba) swarms. Polar Biol 6:83-90

Forward Jr RB, Tankersley RA (2001) Selective tidal-stream transport of marine animals. Oceanogr Mar Biol Annu Rev 39:305-353

Gendron DL (1992) Population structure of daytime surface swarms of Nyctiphanes simplex (Crustacea: Euphausiacea) in the Gulf of California, México. Mar Ecol Prog Ser $87: 1-6$

Genin A (2004) Bio-physical coupling in the formation of zooplankton and fish aggregations over abrupt topographies. J Mar Syst 50:3-20

Gibson RN (2003) Go with the flow: tidal migration in marine animals. Hydrobiologia 503:153-161

Gómez-Gutiérrez J (1995) Distribution patterns, abundance and population dynamics of the euphausiids Nyctiphanes simplex and Euphausia eximia in the west coast of Baja California, México. Mar Ecol Prog Ser 119:63-76

Gómez-Gutiérrez J, Sánchez-Ortíz C (1997) Larval drift and population structure of the pelagic phase of Pleuroncodes planipes (Simpson) (Crustacea: Galatheidae) off the southwest coast of Baja California, México. Bull Mar Sci 61:305-326

Gómez-Gutiérrez J, Robinson CJ (1997) Circadian biomass and abundance changes of five euphausiids along the west coast of Baja California México, December 1993. Sci Mar 61:27-35

Gómez-Gutiérrez J, De Silva-Dávila R, Lavaniegos EB (1996) Growth production of the euphausiid Nyctiphanes simplex at the coastal shelf off Magdalena Bay, Baja California Sur, México. Mar Ecol Prog Ser 138:309-314

Gómez-Gutiérrez J, Palomares-García R, De Silva-Dávila R, Carballido-Carranza MA, Martínez-López A (1999a) Copepod daily egg production and growth rates in Bahía Magdalena, México. J Plankton Res 21:2227-2244

Gómez-Gutiérrez J, González-Chávez G, Robinson CJ, Arenas FV (1999b) Latitudinal changes of euphausiid assemblages related to dynamics of the scattering layer along Baja California, October 1994. Sci Mar 63:79-91

Gómez-Gutiérrez J, Palomares-García R, Hernández-Trujillo S, Carballido-Carranza A (2001) Community structure and distribution of zooplankton through the main entrance of Bahía Magdalena México during 1996. Rev Biol Trop 49: 545-558

Hamner WM (1984) Aspects of schooling in Euphausia superba. J Crustac Biol 4:67-74

Hamner WM, Hamner PP (2000) Behavior of the Antarctic krill (Euphausia superba): schooling, foraging and antipredatory behaviour. Can J Fish Aquat Sci 57(Suppl 3):192-202 
Hamner WM, Hamner PP, Strand SW, Gilmer RW (1983) Behavior of Antarctic krill, Euphausia superba: chemoreception, feeding, schooling, and molting. Science 20: 433-435

Hill AE (1991) A mechanism for horizontal zooplankton transport by vertical migration in tidal currents. Mar Biol 111: 485-492

Hill AE (1995) The kinematical principles governing horizontal transport induced by vertical migrations in tidal flows. J Mar Biol Assoc UK 75:3-13

Kaartvedt S, Røstad A, Fiksen $\varnothing$, Melle W, Torgersen T, Breien MT, Klevjer TA (2005) Piscivorous fish patrol krill swarms. Mar Ecol Prog Ser 299:1-5

Kimmerer WJ, Burau JR, Bennet WA (1998) Tidal oriented vertical migration and position of zooplankton in a temperate estuary. Limnol Oceanogr 43:1697-1709

Lluch-Belda D, Hernández-Rivas M, Saldierna-Martínez RJ, Guerrero-Caballero R (2000) Sea surface temperature variability at Magdalena Bay, Baja California Sur, México. Océanides 15:1-23

MacLennan DN, Simmons J (1992) Fisheries acoustic. Chapman \& Hall, London

MacLennan DN, Fernandes PG, Dalen J (2002) A consistent approach to definitions and symbols in fisheries acoustics. ICES J Mar Sci 59:365-369

Marta-Almeida M, Dubert J, Peliz A, Queiroga H (2006) Influence of vertical migration pattern on retention of crab larvae in a seasonal upwelling system. Mar Ecol Prog Ser 307:1-19

Mufti P, Weise K (2004) Swimming in formation in krill (Euphausiacea), a hypothesis: dynamics of the flow field, properties of antennular sensor systems and a sensorymotor link. J Plankton Res 26:1315-1325

Palomares-García R, Vera-Alejandre R (1995) Predation upon larvae of the pelagic sardine Sardinops sagax by cyclopoid copepods. J Crustac Biol 15:196-201

Palomares-García R, Gómez-Gutiérrez J (1996) Copepod community structure at Bahía Magdalena, México during El Niño 1983-1984. Est Coast Shelf Sci 43:583-595

Palomares-García R, Martínez-López A, De Silva-Dávila R, Funes-Rodríguez R, Carballido-Carranza MA, Avendaño-

Editorial responsibility: Otto Kinne (Editor-in-Chief), Oldendorf/Luhe, Germany
Ibarra R, Hinojosa-Medina A, López-Ibarra GA (2003) Biological effects of El Niño 1997-98 on a shallow subtropical ecosystem: Bahía Magdalena, México. Geofis Int 42: 455-466

Ressler PH, Brodeur RD, Peterson WT, Pierce SD, Vance PM, Røastad A, Barth JA (2005) The spatial distribution of euphausiid aggregations in the Northern California Current during August 2000. Deep-Sea Res Part II 52:89-108

Ritz DA (1994) Social aggregation in pelagic invertebrates. Adv Mar Biol 30:156-206

Robinson CJ, Gómez-Aguirre S (2004) Tidal stream use by the red crab Pleuroncodes planipes in Bahía Magdalena, México. J Exp Mar Biol Ecol 308:237-252

Robinson CJ, Gómez-Gutiérrez J (1998a) Daily vertical migration of dense scattering layers related to shelf-break area in the northwest coast of Baja California, México. J Plankton Res 20:1679-1697

Robinson CJ, Gómez-Gutiérrez J (1998b) The red-crab bloom of the west coast of Baja California, México. J Plankton Res 20:2009-2016

Robinson CJ, Anislado V, Ramos P (2004) Shoaling fish and red crab behaviour related to tidal variations in Bahía Magdalena, México. Deep-Sea Res II 51:767-783

Sánchez-Montante O (2003) Hidrodinámica y transporte de masa en el sistema lagunar de Bahía Magdalena-Bahía Almejas, Baja California Sur, México: modelación y experimentación. PhD thesis, Centro Interdisciplinario de Ciencias Marinas, La Paz

Shanks AL, Brink L (2005) Upwelling, downwellings, and cross-shelf transport of bivalve larvae: test of a hypothesis. Mar Ecol Prog Ser 302:1-12

Simrad (2003) Operation manual Simrad ER-60. Scientific echo sounder applications, Horten

Strand SW, Hamner WM (1990) Schooling behavior of Antarctic krill (Euphausia superba) in laboratory aquaria: reactions to chemical and visual stimuli. Mar Biol 106: 355-359

Zaytsev O, Cervantes-Duarte R, Sánchez-Montante O, Gallegos-García A (2003) Coastal upwelling activity on the Pacific shelf of the Baja California peninsula. J Oceanogr 59:489-502

Submitted: August 4, 2005; Accepted: February 16, 2006 Proofs received from author(s): August 2, 2006 